\title{
Harmonization of Brazilian Popular Songs
}

\author{
Silvio Augus to Merhy
}

Instituto Villa-Lobos, Universidade Federal do Estado do Rio de Jan eiro, Unirio, Rio de Jan eiro, 22290-240, Brazil

\begin{abstract}
Harmonization of popular songs in Brazil has, for quite some time, been considered worthy of the attention of both music theorists and musicologists. Theaccompanimentsattract attention due to their varied and sometimes original character. The peculiarities of the harmonization of popular Brazilian songs may not always be immediately comprehensible, nor correspond exactly to conventions found in analyses of the traditional concert repertoire. The chief reference treatises and manuals adopted in music schools can certainly provide satisfactory explanations, when appropriately used. Yet many specialists consider problematic some concepts and definitions that should facilitate the task of analysing popular songs. The Manual of Harmony by Igor VladimirovichSpossobin, 1955 edition, is the textbook adopted for harmony classes in the undergraduate program at the Universidade Federal do Estado do Rio de Janeiro - Unirio. Considered one of the most complete on the topic,it is also used at the Tchaikovsky Conservatory in Moscow. The 2007 edition is also used for reference.Nevertheless, it is worth mentioning that the book has not been used intensively for the analysis of popular songs. The Manual covers 60 topics, some of which are useful in explaining harmonic language frequently present in popular songs. Concepts such as inclination, the major-minor system, augmented sixth chords, Neapolitan harmonies, ellipse, dimin ished-seventh chords and chords with non-chord tones, can be used to explain many of the harmoniesheard in Brazilian popular songs.
\end{abstract}

Keywords Harmony, Brazilian Popular Songs, Musical Analysis

\section{Introduction}

Music theorists and musicologists in Brazil have been turning their attention to the harmonization of popular songs for decades, because of its variable and sometimes original uses.The harmonic peculiarities of Brazilian popular songs necessitate clarification since they do not correspond exactly to the time-honoured conventions of the traditional repertoire.

The best-known instructional manuals adopted by music institutions provide acceptable explanations. These books contain concepts and definitions ready to use in exercises, but up to now have seemed difficult for some experts, and thus have not been used intensively for the analysis of popular songs.

The undergraduate music program at the Univers idade Federal do Estado Rio de Janeiro - Unirio, has adopted the Manual for Harmony by Igor VladimirovichSpossobin as its textbook for the field. While the 4 th edition has been used at Unirio since 1970[1], the more recent, 2007 edition is now being used as well. The book has also been adopted at the Moscow Conservatory. The Manual covers 60 topics, some of which are useful inexplainingharmonic language of

\footnotetext{
* Corresponding author:

simerhy@globo.com(Silvio Augusto Merhy)

Published online at http//journal.sapub.org/edu

Copyright (C) 2012 Scientific \& Academic Publishing. All Rights Reserved
}

popular songs. Concepts such as inclination, the majorminor system, augmented sixth chords, Neapolitan harmonies, ellipse, diminished-seventh chords and chords with non-chord tones can be used to explain many of the harmonies heard in Brazilian popular songs. Similar explanationsappear in related worksby such authorsas Almir Chediak[2], Arnold Schoenberg[3], Ian Guest[4], Joaquin Zamaco is[5], Nicolas Rims ki-Korsakov[6], Paulo Silva[7], Philip Tagg[8] and Walter Piston[9].

\section{Selecting the Repertoire to be Analyzed}

Brazilian popular song refers as much to the object of study as to the production of tunes sung in Portuguese. In any event, the current analys is encompasses songs with Brazilian Portuguese lyrics. The study is not restricted to a particular time period, since doing so might lead to mistakes. As an example, the harmonic complexity frequently associated with Bossa Nova would seem to be at odds with the fact that songs recorded before 1950 contained non-diatonic harmonic progressions similar to those used after that period of time. For this reason, questions about the correspondence between genres, styles and period of time were put aside.

As an illustration, examples of the use of inclination include "Vira a casaca", a song originally recorded in 1923 and remastered in 1996, played by Pixinguinha and the band Os Oito Batutas. 


\section{Spossobin's Concepts and Their Applicability to the Concepts Used in the Analysis of Popular Songs ${ }^{1}$}

\subsection{Inclination}

In the 31st Theme of the Manual, page 235[1], Spossobin defines inclination as "briefly leaving the principaltonality and moving into a secondary tonality during the exposition of a monotonic or modulating structure (period). There are two types of inclination: passing and cadential. The passing inclination occurs inside the structure, without the cadence, it is similar to the passing tone or passing chord."

On page 234 of the Manualthe author distinguishes inclination from modulation as "passing into a new tonality to conclude the musical structure in that tonality. As a rule, modulation ends in a complete cadence. The simplest modulation is that which substitutes the tonality at the end of the first period[1]."

Table 1. Examples of Songs with Inclinations

\begin{tabular}{|c|c|c|}
\hline \multirow{2}{*}{\multicolumn{3}{|c|}{$\begin{array}{c}\text { 1. "Vira a casaca" (Support another T eam) by Joubert de Carvalho } \\
\text { and Gáudio Viotti }\end{array}$}} \\
\hline & & \\
\hline & & Chord progression: $\mathrm{E} 7 / \mathrm{B}\left|\mathrm{AmF} \#^{\circ}\right| \mathrm{C} / \mathrm{G}$ Dm G7| C \\
\hline & & Analysis:V/VI|VIm \#IV ${ }^{0} \mid \mathrm{I} / \mathrm{VIIm}$ V7|I \\
\hline & & Placed at the second phrase of the second part. \\
\hline & & 2. “João e Maria” (John and Mary) by Chico Buarque and Sivuca \\
\hline & & Key: A minor \\
\hline & & Chord progression: Am7 |Dm7|G7 |Gm7|C7|F7M \\
\hline & & Analysis:Im7[IIm7|V7 |IIm7|V7|VI7M \\
\hline & & $\begin{array}{c}\text { Corresponding lyrics:“...E pelaminha lei a gente era obrigada a } \\
\text { serfeliz...” }\end{array}$ \\
\hline & & $\begin{array}{c}\text { 3. "Água de beber" (Drinking water) by Tom Jobim and Vinícius de } \\
\text { Moraes }\end{array}$ \\
\hline & & Key: B minor \\
\hline & & Chord progression: E7(9)|Em7(9)A7(13)|D7M(9) \\
\hline & & Analysis:V7(9)|IIm7(9) V7(13) |I7M(9) \\
\hline & & Corresponding lyrics: “...E quissalvarmeucoração...”" \\
\hline & & 4. "Look to the sky" by Tom Jobim \\
\hline & & Key: E flat major \\
\hline & & Chord progression: Abm7 |Db7 |Gb7M \\
\hline & & Analysis:IIm7 |V7 |bIII7M \\
\hline & & Placed at the final part of the song. \\
\hline & & $\begin{array}{l}\text { 5. "O bêbado e a equilibrista" (The alcoholic andthe man on wire) by } \\
\text { JoãoBosco and Aldir Blanc }\end{array}$ \\
\hline & & Key: A major \\
\hline & & $\begin{array}{l}\text { Chord progression: A7M }|\mathrm{C} \# \mathrm{~m} 7(\mathrm{~b} 5) \mathrm{F} \# 7| \mathrm{Bm} 7|\mathrm{D} 7 \mathrm{M}| \mathrm{Bm} 7 \mathrm{E} 7(9) \\
\mid \mathrm{C} \# \mathrm{~m} 7\end{array}$ \\
\hline & & Analysis:I7M |IIm7(b5)V7/II IIIm7 |IV7M |IIm7 V7/I |IIIm7 \\
\hline & & $\begin{array}{c}\text { Corresponding lyrics:“... e um bêbadotrajandoluto me } \\
\text { lembrouCarlitos, }\end{array}$ \\
\hline & & $\begin{array}{l}\text { A lua, tal qual a dona de um bordel, pedia a cadaestrelafria um brilho } \\
\text { dealuguel" }\end{array}$ \\
\hline & & $\begin{array}{c}\text { 6. "Na intimidademeupreto" (Intimately, I'll call you my black) by } \\
\text { Nei Lopes }\end{array}$ \\
\hline & & Key: F major \\
\hline & & Chord progression: $\mathrm{F}|\mathrm{Gm} 7 \mathrm{C} 7| \mathrm{F}|\mathrm{F} 7| \mathrm{Bb} 6$ \\
\hline & & Analysis:I|Im7V7 |I|V7/IV|IV6 \\
\hline & & $\begin{array}{c}\text { Corresponding lyrics: “Quandoeusaiopragandaiaelafaz um escarcéu, } \\
\text { Dizendoqueeunãovalho nada, E que a grandeculpada é aPrincesa } \\
\text { Isabel”" }\end{array}$ \\
\hline
\end{tabular}

\footnotetext{
${ }^{1}$ The author translated the originals.
}

This defin ition coincides with the notion of inclination as taught in both schools of music and in well-known manuals. Inclination is a harmonic technique that appears in the majority of songs. For this reason it may not be appropriate to group repertoire by its country of origin or a specific time period.However it is important to note that the process of inclination applied to some songs can be slightly different from the above definition.

The notion of inclination is frequently replaced by the concept of secondary dominants, more often used to explain harmonization in popular music. AlmirChediak[2] and Ian Guest[4] have consistently used it as an alternative to the term inclination. The concepts of secondary dominants and tonics are also explained in the 32nd Theme of the Spossobin's Manual. There are many songs in which secondary dominants are combined with secondary or interpolated subdominants and followed by deceptive cadences (ellipsis), as in the passages shown below.

Most of the examples listed below have already been discussed in my dissertation, "Bossa Nova: a permanência do samba entre a preservação e a ruptura" (Bossa Nova: the endurance of samba amid preservation and rupture)[9].

\subsection{Major-Minor System}

The major-minor system is an important aspect of harmonic analysis. Spossobindefines the concept on page $374[1]$ of the $49^{\text {th }}$ Theme: "in the development of the idea of modality, the major and the minor modes have never had an isolated, independent existence. On the contrary, it has long been noted that changes, linked to the interaction of both modes, have produced complexities through the insertion of harmonic elements from either mode, which, as a result, become richer. The major and minor modalities become more complex due to their interaction and form the major-minor system, named major-minor or minor-major, depending on the leading tonic, major or minor.The system can be homonymous if they share the same tonic (for example $\mathrm{C}$ major - $\mathrm{C}$ minor) or parallel (for example $\mathrm{C}$ major - A minor)."

Modal interchange has been widely used in popular music. Philip Tagg points out that bitonality is common in many popular styles of Latin American music (page 10) [8]. Chords from the minor mode are often inserted in a song whose prevailing tonality is in the major mode. On the contrary, inserting major mode chords in a progressionwhose principal tonality is in the minor mode is much less common. The exception to this is the Picardy third, used both in traditional and popular music.

The idea of modal interchange comes closer toSpos sobin's definition, due to the fact that major and minor mode are often mixed together. It is important to consider additional modal interchanges, which occur in the church modes:Mixolydian, Lydian, Phrygian and Dorian. In his book, Theory of Harmony, Arnold Schoenberg describes the genesis of the major and minor modes and considers them "both a residue of the seven church modes"[3]. 
However, modal interchange in popular music typically occurs when the major and minor tonics are the same, or homonymous. In Walter Piston's Harmony[10] he exp la ins modal interchange along with the idea that the minor mode runs parallel to the major. The same notion appears in Spossobin'sManual, yet the minor mode is not the homonymous but the relative, which shares the same key signature as the corresponding major.

The major-minor system comprises the modal interchange concept as demonstrated below:

Table 2. Examples of Songs in Major-Minor System

\begin{tabular}{|c|}
\hline 1. Look to the sky by Tom Jobim \\
\hline Key: E flat major \\
\hline Chord progression: Abm7 $|\mathrm{Db} 7| \mathrm{Gm} 7$ \\
\hline Analysis:IVm7 bVII7 [IIIm7 \\
\hline Placed at the second phrase of the first part. \\
\hline $\begin{array}{c}\text { 2. "O bêbado e a equilibrista" (The alcoholic and the man on wire) } \\
\text { by JoãoBosco and Aldir Blanc }\end{array}$ \\
\hline Key: A major \\
\hline Chord progression: $\mathrm{Dm} 7|\mathrm{G} 7(13)| \mathrm{D} \#^{\circ} \mathrm{A} 7 \mathrm{M}$ \\
\hline Analysis:IVm7|bVII7(13) |I'I7M \\
\hline Corresponding lyrics:“...Louco, o bêbado com chapéu-coco...” \\
\hline 3. "Luiza" by Tom Jobim \\
\hline Key: C minor \\
\hline Chord progression: D7(b9) $\mid \mathrm{G} 7$ (b9) $\mid \mathrm{C} 7 \mathrm{M}(9)$ \\
\hline Analysis:V7(b9) $\mid \mathrm{V} 7(\mathrm{~b} 9)[\mathrm{I} 7 \mathrm{M}$ \\
\hline $\begin{array}{l}\text { Corresponding lyrics:“....Escuta agora a } \\
\text { cançãoqueeufizprateesquecer, Luiza...” }\end{array}$ \\
\hline 4. "Gatasextraordinárias" (Amazing babies) by Caetano Veloso \\
\hline Key: E major \\
\hline $\begin{array}{c}\text { Chord progression: E7M }|\mathrm{Bm} 7| \mathrm{E} 7(13)|\mathrm{A} 6| \mathrm{Am} 6 \\
|\mathrm{G} 6| \mathrm{C} 7 \mathrm{M}|\mathrm{F} \# 7| \mathrm{B} 7(\mathrm{bl} 3) \mid \mathrm{Em} 7 \\
\end{array}$ \\
\hline $\begin{array}{c}\text { Analysis:I7M |IIm7/IV |V7/IV |IV6 IIVm6|bIII6 |bVI7M|V7/V } \\
\text { |V7|Im7 }\end{array}$ \\
\hline Placed at the first phrase. \\
\hline
\end{tabular}

\subsection{Aug mented Sixth Chord}

The harmonic structure known as subV has been increasingly used in popular music, both in the harmonization and re-harmonization of songs. The so-called subV chord has as its main characteristic the augmented sixth, which is derived from the inversion of the diminished third between the major third and the diminished fifth of the dominant chord. Hence, it may be more useful to think of it as the second inversion of the do minant chord with a lowered fifth, where its diminished third is converted to an augmented sixth. Both Schoenberg and Pistonconsidered this an important topic, and dedicated complete chapters to it.

The repeated use of this chord may overshadow the fact that it is simply an alteration or variation of a do minant chord with a lowered fifth.

Spossobin describes these altered chords as comprising not only the lowered II degree of the major mode (which is the fifth of the dominant chord) but other possible altered tones inserted in a variety of chords on different scale degrees. He states, "As is well known, the alteration represents the intensification of a semitone in the tension of a whole tone existing in the mode, withoutchanging the chord function and without leaving the respective tonality. The corresponding chord is called an altered chord. Altered harmonic compounds have their origin in chromatic passing tones in different voices inside the diatonic mode. The basic alteration present in most harmonic functions is associated with the change of the II degree of the scale. Its alteration in the major mode can be done by raising or lowering it; in consequence, the intensification of the tension occurs toward the tones of the lower third of major tonic triad, i.e., toward the I and the III scale degrees. In the minor mode, ra ising the II degree is not possible, thus the alteration in thatmode is based exclusively by lowering the II degree and, to some extent by altering the IV degree. Consequently the intensification of the tension occurs toward the lower third of the tonic minor triad[1]."

This quotation makes clear the orig in of the chord alteration.The harmonic situation is quite common and can be heard in various songs, of which three were selected.

Table 3. Examples of Songs with Augmented Sixth Chord

\begin{tabular}{|c|}
\hline 1. "Luiza" by Tom Jobim \\
\hline Key: Cminor \\
\hline Chord progression: D7(9) $|\mathrm{Dm} 7(9) \operatorname{Db} 7 \mathrm{G} 7(\mathrm{~b} 5)| \mathrm{Cm} 7(9)$ \\
\hline Analysis:V7(b9) $\operatorname{IIm} 7(9) \mid \mathrm{V} 7 / \mathrm{b} 5 \mathrm{V7}(\mathrm{b} 5) \operatorname{Im} 7(9)$ \\
\hline $\begin{array}{c}\text { Corresponding lyrics:“...Acordaamor, queeuseiqueembaixodesta } \\
\text { neve mora um coração..." }\end{array}$ \\
\hline 2. "Sót inha de ser com você" (It must be you) by Tom Jobim \\
\hline Key: F major \\
\hline $\begin{array}{c}\text { Chord progression:F7M }|\mathrm{C7}(\# 9)| \mathrm{F} 7 \mathrm{M}|\mathrm{Gb} 7(\mathrm{~b} 13)| \mathrm{Cm} 7(9) \mid \mathrm{Bm} 7(\mathrm{~b} 5) \\
\text { Bbm6 (9) }\end{array}$ \\
\hline $\begin{array}{c}\text { Analysis:I7M |V7(\#9)|I7M|subV7(b13) }|\operatorname{Im} 7(9) / I V| \# I V m 7(b 5) \\
\operatorname{IVm6(9)}\end{array}$ \\
\hline $\begin{array}{l}\text { Placed inthe first phrase. } \\
\end{array}$ \\
\hline $\begin{array}{l}\text { 3. "Derradeira primavera" (Ult imate springtime) by Tom Jobim and } \\
\text { Vinícius de Moraes }\end{array}$ \\
\hline Chord progression: $\mathrm{Dm} 7|\mathrm{E} 7| \mathrm{Bb} 7 \mid \mathrm{Am} 7$ \\
\hline Analysis:IVm7|V7 |bII7|Im7 \\
\hline Placed at the end of the song. \\
\hline
\end{tabular}

\subsection{Ne apolitan Har monies}

The lowered II degree can often be detected in the harmonization of popular songs. It shows up most frequently in the $\mathrm{bII}^{7 \mathrm{M}}$ root position form. The most common way to explain it is through its origin from the Phrygian mode, considered a modal interchange.

The shape of this structure however, may be explained by its origin, as described by Spossobin on page 352 of the $47^{\text {th }}$ Theme: "The most significant and commonaltered subdominant chord is ${ }_{\mathrm{b} 1} \mathrm{sII}$, formed by the sII of the minor and the harmonic major mode, through the alteration of the chord's root. In addition to the lowered fifth of the minor subdominant chord, the first inversion contains an altered sixth, formed between the lowered root and the third of thechord.This lowered II major triad in its first inversion is the Neapolitan sixth chord, sometimes called Neapolitan harmony. It first appeared in works of XVII century composers from the Neapolitan Opera School (A. Scarlatti, A. Stradella and others), as a Phrygian minor mode harmon ic compound[1]."

Spossobingoes on to explain the use of the seventh in 
Neapolitan harmony: "A passing tone between the ${ }_{b 1} \mathrm{SII}_{6}$ altered tone and the dominant third gradually created a new Neapolitan harmony - the Neapolitan seventh chord $\left({ }_{\mathrm{b} 1} \mathrm{SII}_{7}\right)$. Combining $\mathrm{s}$ and ${ }_{\mathrm{b} 1} \mathrm{SII}_{6}$ in the major and minor mode altogether shaped it. It is a major chord due to themajor triad and its seventh[1]."

Indeed, the appearance of the Neapolitan chord in root position is quite peculiar: "Later, the lowered II triad in root position appeared. Originating from the Neapolitan sixth chord, it emerged in a singular way, as if it had been an inversion form the original chord[1]."

Table 4. Examples of Songs with Neapolitan Harmonies

\begin{tabular}{|c|}
\hline 1. "Gema" (Gem) by Caetano Veloso \\
\hline Key: G major \\
\hline Chord progression: Cm F7(9)|Bb Bb7|Eb7M Ab7M |Am7(11) \\
\hline Analysis:IIm7 V7/bIII|bIII V7/bVI |bVIbII7M |IIm7(11) \\
\hline Corresponding lyrics:“...esquecer, não, me perder, não...” \\
\hline $\begin{array}{c}\text { 2. "Bronzes e cristais" (Bronzes and crystals) by AlcyrP iresVermelho } \\
\text { and Nazareno de Brito. }\end{array}$ \\
\hline Key: F major \\
\hline Chord progression: F7|Bb7|Eb7|Ab7|Db7|Gb7M |C7|F7M \\
\hline Analysis:V7|V7 |V7|V7|V7|bII7M|V7|I7M \\
\hline Placed at the last phrase of the song. \\
\hline
\end{tabular}

\subsection{Ellipsis}

In linguistics, ellipsis (from the Greek élleipsis, "omission") refers to the absence of one or mo re words from a clause. In Spossobin's Manual it refers to the lapse of an expected resolution. Other designations, such as deceptive cadence, deceptive resolution and irregular resolution appear in Schoenberg's Theory of Harmony, page 136[3], and Piston's Harmony, page 191[10]. The concepts of ellipsis and irregular resolution have not been applied to the harmonic analysis of popular music. In some cases these terms were replaced by extended and consecutive dominants that deal specifically with a dominant chord resolution in which the tonic preserves the major triad but adds a minor seventh, changing it to a dominant chord (Chediak, page 266[2], and Guest, page 99 volume 1[4]). The concept of extended dominants is related to a generic jazz notion that defines a dominant chord as a preparation chord: due to its tension it can prepare or precede any chord placed a fifth below. For example, the dominant of the dominant chord (V7 - V7), a secondary dominant, involves a situation in which a dominant chord precedes another chord with the same structure and does not have the expected resolution, typically to a stable major or minor chord. According to Spossobin, the double dominant chord, as defined in the Manual, does not characterize ellipsis as long as the resolution is not omitted. On the other hand, ellipsis does take place in the case of consecutive dominants since the resolution chords are continuously replaced.

The notion of ellipsis does not appear in Chediak and Guest, but is replaced by the deceptive resolution, the same as described by Schoenberg, (page 137): "This term is understood to mean the substitution for the expected progression, V-I" [3], and mentioned by Philip Taggon in his article Troubles with tonal terminology, page 9[8]. Guest (page 70, volume 2) describes it as follows: "The deceptive resolution occurs when the dominant chord does not lead to the predictable resolution"[4].

Spossobin explains the term on page 426 of the $56^{\text {th }}$ Theme: "Literally meaning absence or omission, ellipsis is formed by replacing the expected chord with any other without delay, in the functional sequence of the first chord. Ellipsis juxtaposes two chords that have no immediate relation such as dominant and tonic, subdominant and tonic or DD and D[1]."

Harmonic progressions, understood as extended and consecutive dominants, are explained on page 430: "the expected tonic chord is replaced by the dominant seventh chord, built on the same bass note of the tonic chord, so as to create the dominant cycle, ending, in most cases, with D7 of S or SII[1]."

The use of extended dominants is one of the harmonic situations that can be called ellipsis in popular music. Sometimes the resolution to extended dominants is delayed due to the interpolation of a subdominant chord. Interpolated subdominants can appear in situations as often in ellipsis as in inclinations. (See the examples of inclination above).

Table 5. Examples of Songs with Ellipsis

\begin{tabular}{|c|}
\hline $\begin{array}{l}\text { 1. "Joana, a Francesa" (Joana, the French) by Chico Buarque and } \\
\text { Francis Hime }\end{array}$ \\
\hline Key: C major \\
\hline Chord progression: Dm7 /E $|\mathrm{F} 7 \mathrm{M}| \mathrm{Bbm} 6|\mathrm{~A} 7| \mathrm{D} 7 \mid \mathrm{G} 7$ \\
\hline Analysis:IIm7|IV7M|bVIm6|V7 |V7 |V7 \\
\hline $\begin{array}{c}\text { Corresponding lyrics: “Treme de preguiça e de suor, já é } \\
\text { madrugada..." }\end{array}$ \\
\hline 2. "Chorinhopraele" (Chorinho for him) by HermetoPascoal \\
\hline $\begin{array}{l}\text { Chord progression: F7 Bb7 |Eb7 Ab7 |Db7 C7 |F7 } \\
\end{array}$ \\
\hline $\begin{array}{l}\text { Analysis:V7 V7|V7 V7|V7 V7 |V7 } \\
\end{array}$ \\
\hline Placed at the introduction. \\
\hline 3. "A rã" (The frog) by JoãoDonato and Caet ano Veloso \\
\hline Key: F major \\
\hline $\begin{array}{c}\text { Chord progression: A7(13) A7(b13)|D7 D7(b13) |Bb7M|C7(13) } \\
\text { |D7M }\end{array}$ \\
\hline Analysis:V7|V7|V7|V7|V7 \\
\hline Final cadence. \\
\hline $\begin{array}{c}\text { 4. "Estrada do sol" (Road to the sun) by Tom Jobim and Dolores } \\
\text { Duran }\end{array}$ \\
\hline Key: F major \\
\hline Chord progression: Bbm7 $|\mathrm{Eb} 7| \mathrm{Am} 7|\mathrm{D} 7(9)| \mathrm{Abm} 7|\mathrm{Db} 7(9)| \mathrm{Gm} 7 \mid \mathrm{C} 7$ \\
\hline 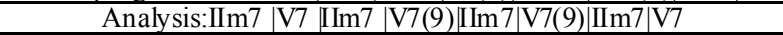 \\
\hline Corresponding lyrics: “...queroquevocê me dê a mão...” \\
\hline 5. "Sót inha de ser com você" (It must be you) by Tom Jobim. \\
\hline Key: F major \\
\hline Chord progression: A7 $|\mathrm{D} 7| \mathrm{G} 7|\mathrm{C} 7| \mathrm{F} 7 \mathrm{M}$ \\
\hline Analysis:V7/VI|V7/II |V7/V|V/I|I7M \\
\hline Placed at end of the first phrase. \\
\hline
\end{tabular}

\subsection{The Seventh Diminished Chord}

The seventh diminished chord is commonly designated as a diminished chordon the VII degree of the harmonic minor scale. This chord has become, for many reasons, one of the most useful harmonic elements in popular music. As a result, its origin from the harmonic minor scale has been forgotten in various harmonic progressions and does not even appear in the chord symbol used to notate the dimin ished chord. 
Chord symbol notation is, by and large, insufficient to represent harmonic elements. Conventionally it does not indicate the inversion as commonly used for all other chord labels, as for example, $\mathrm{D}^{\circ}$ would stand for $\mathrm{B}^{\mathrm{o}} / \mathrm{D}$. In some harmonic progressions the chord symbol of a root position is given, though it is actually an inversion. This kind of simplification has some advantages, though it may cause misunderstandings. In any case, one should note that the same chord symbol used for root positionmightbe used to represent an inversion of other chords, sometimes as an enharmonic equivalent.

In general, in popular music diminished chords has two different functions:

- As a dominant chord of the seventh degree, which precedes the tonic chord.

- As an element derived from the combination of altered tones.

Both can appear as auxiliary or chro matic passing chords, sometimes without the dominant function. A passing chord can be explained as follows: the bass note of a diminished chord becomes a passing tone between two other bas notes, in ascending or descending stepwise motion.

Diminished chords preceding secondary tonics can be easily seen as having dominant function because they are related to the tonic as its seventh degree.

Diminished chords, however, do not have a dominant function when resulting from some other chords in which altered notes or non-chord tones are inserted. In any case, the melodic relation prevails over the harmon ic relation: melodic motion in inner voices is made by chromatic or diatonic approach notes and prevails over the harmon ic relation. They are voice-led chords and are designated as approach chords having no dominant function at all, regard less of whether the root moves up or down stepwise.

On the contrary, the seventh degree diminished chord is always connected to the resolution, up one degree in root positionor other intervals, depending on its inversion.

Dimin ished chords may link neighbouring diatonic chords by moving the bass up or down. They are known as passing diminished chords because of the chromatic passing tone in the bass. However, they can function as auxiliary chords $\left(\mathrm{I}^{\mathrm{o}}\right.$ or $\mathrm{V}^{\mathbf{0}}$ ) when they have the same bass note as the first and the fifth degrees.

In Spossobin's Manual,diminished chords are not dealt with in one exclusive Theme (chapter). In the $22^{\text {nd }}$ Theme they are explained in the context of the seventh degree of the minor scale, together with the seventh degree of the major scale, which, though built differently, has the same dominant function. The use of the VII chord of the major scale is not as widespread as that of the minor. However, the examples presented in the book are useful for both major and minor modes.

In the $57^{\text {th }}$ Theme, devoted to enharmonic modulation, the diminished chord is dealt with exhaustively on page 439: "Enharmonic modulation by way of the diminished seventh chord is one of the most widespread examples of abrupt changes in tonality and a consequence of the universal possibilities inherent in this chord. Th is type of modulation is based on the fact that dimin ished chords, in terms of sonority, have only three possibilities, though they can be formed on any of the twelve pitches of the chro mat ic scale. Thus each of the three inversions of the seventh diminished chord can resolve to any tonality as the leading tone of T, S or D[1]."

The examples are very specific and comply with the chord resolution and in every enharmonic situation. The correct notation is consistent with the expected tonality and the prevailing key signature.

The $57^{\text {th }}$ Theme deals with the diminished chord involving only the dominant function on the seventh scale degree. In other harmonic situations that include the dimin ished chord, the chord in question is built with non-chord tones.

The examp les below demonstrate two types of dimin ished chords: as a seventh degree chord and as an auxiliary chord formed with auxiliary notes. Both types can feature passing chords, unlike the auxiliary chord that can never have dominant function.

Table 6. Examples of Songs with Seventh Diminished Chords

\begin{tabular}{|c|}
\hline 1. Avarandado (Terraced) by Caetano Veloso \\
\hline Key: A major \\
\hline Chord progression: E7 $\left|\mathrm{A}^{\circ}\right| \mathrm{A} 7 \mathrm{M}$ \\
\hline Analysis:V7 $\left|\mathrm{I}^{\circ}\right| \mathrm{I7} \mathrm{M}$ \\
\hline Corresponding Lyrics: “...T em umamoçarecostada...” \\
\hline 2. "Discussão" (Argument) by Tom Jobim and Vinícius de Moraes \\
\hline Key: C major \\
\hline Chord progression: $\mathrm{C} 7 \mathrm{M}\left|\mathrm{Eb}^{\circ}\right| \mathrm{D} 7 \mathrm{~m}\left|\mathrm{D} \#^{\circ}\right| \mathrm{Em} 7$ \\
\hline $\begin{array}{c}\text { Analysis:I7M|bII }{ }^{\circ}|\operatorname{Im} 7| \# I I \mid I I m 7 \\
\end{array}$ \\
\hline Corresponding lyrics: "Se vocêpret endesustent ar a opinião..." \\
\hline 3. "Entrudo" (Carnival parade) by Carlos Lyra \\
\hline Key: B minor \\
\hline Chord progression: $\mathrm{Bm} 7\left|\mathrm{~A} \#^{\circ}\right| \mathrm{Am} 7 \mid \mathrm{D} 7$ \\
\hline Analysis: $\operatorname{Im} 7\left|\mathrm{VII}^{\circ}\right| \operatorname{IIm} 7 \mid \mathrm{V} 7$ \\
\hline $\begin{array}{c}\text { Corresponding lyrics:"Vem, ó minhaamada, desce a estrada de } \\
\text { rainha..." }\end{array}$ \\
\hline $\begin{array}{l}\text { 4. "Euseiquevout eamar" (I know I will love you) by Tom Jobim and } \\
\text { Vinícius de Moraes }\end{array}$ \\
\hline Key: C major \\
\hline Chord progression: $\mathrm{C} 7 \mathrm{M}\left|\mathrm{Eb}^{\circ}\right| \mathrm{Dm} 7$ \\
\hline Analysis: $17 \mathrm{M}\left|\mathrm{b} \Pi I^{\circ}\right| \operatorname{Im} 7$ \\
\hline $\begin{array}{c}\text { Corresponding lyrics: "Euseiquevout eamar, portoda a } \\
\text { minhavidaeuv out eamar..." }\end{array}$ \\
\hline $\begin{array}{c}\text { 5. "Feionão é bonito" (It is ugly, not beautiful) by Carlos Lyra and } \\
\text { GianfrancescoGuarnieri }\end{array}$ \\
\hline Tonalidade: Lá m \\
\hline Harmonização:Dm7|D\# $|\mathrm{Am} 7 / \mathrm{E}| \mathrm{F} 7 \mathrm{M}$ \\
\hline Análise:IVm7 $\left|\# \mathrm{IV}^{\circ}\right| \operatorname{Im} 7 / 5 \mid \mathrm{VI} 7 \mathrm{M}$ \\
\hline Localizar:“...Ama, o morroama...” \\
\hline 6. "Look to the sky" by Tom Jobim \\
\hline Key: E flat major \\
\hline Chord progression: $\mathrm{Gm} 7\left|\mathrm{~Gb}^{\circ}\right| \mathrm{Fm} 7$ \\
\hline Analysis:IIm7 $\left|\mathrm{bIII}{ }^{\circ}\right| \operatorname{IIm} 7$ \\
\hline Placed at the end of the first phrase. \\
\hline
\end{tabular}

\subsection{Chords with Non-chord Tones}

The notion of a chord as a tertian structure is crucial to understanding the methodology used in Spossobin's Manual. Basedon tertian structure, it is possible to view non-chord tones as relevant to distinguish between a chord and other types of harmonic compounds. The expression "harmonic compound" was created to translate the Russian word сосвучие, meaning notes sounding together. It is explained 
early in the introduction where the author defines both concepts.

Harmonic compounds, or сосвучиe, refer to non-harmonic tones or non-chord tones. Similar to the 'non-harmonic' tones discussed by Schoenberg, (page 309[3]) and Piston, (page 109[10]): these are also defined in the introduction but developed in later chapters. Some of them are dealt with in separate chapters, for example the delayed notes are in the $36^{\text {th }}$ and $37^{\text {th }}$ The mes, passing tones in the $38^{\text {th }}, 39^{\text {th }}$ and $41^{\text {st }}$ Themes.

Unlike tert ian chords, harmonic co mpounds are formed by intervals other than thirds: they are random structures that appear accidentally in the melodic-harmonic relationship. The $44^{\text {th }}$ Theme defines how these structures can be shaped, rather differently than the tertian chord.

Nevertheless, the accumulation of non-chord tones can occasionally form structures in thirds and are similar to the diatonic chords without the corresponding harmonic function. Dimin ished chords without dominant function are included here. While their structure is actually tertian,their function does not correspond to the seventh scale degree of the harmonic minor.

There are other harmonic situations in which chords do not correspond to their apparent function, such as minor chords that become dominant chords through the insertion of an altered tone. Despite this modification they maintain their original function.

The sus 4 chord can be explained in much the same way: the perfect $4^{\text {th }}$ is inserted as a suspended tone, but is considered part of the chord because of its intensive use. Due to its repeated use over time, the delayed tone lost its sense of novelty.There are nu merous songs containing the perfect 4 th, of which a few were selected for the list below.

Table 7. Examples of Songs with Chords with Nonchord Tones

\begin{tabular}{|c|}
\hline 1.\#IVm7(b5): \\
\hline "Aula de matemát ica"(Mathematics lesson) by Tom Jobim and \\
Marino Pinto \\
\hline Key: Fmajor \\
\hline Chord progression: Gm7 Bbm/C|Bm7(b5)|Bbm6 \\
\hline Analysis:IIm7 V74(b9) $\# \mathrm{IVm} 7(\mathrm{~b} 5)[\mathrm{IVm} 6$ \\
\hline Placed at the end part. \\
\hline 2. Seventh diminished chord modified: \\
\hline "Euseiquevouteamar" by Tom Jobim and Vinícius de Moraes \\
\hline Key: C major \\
\hline Chord progression: Am6|Abm6|C7M \\
\hline Analysis:VIm6 |bVIm6 |I7M \\
\hline
\end{tabular}

\section{Conclusions}

Harmonic analysis can be applied not only to scores of classical music, but also to aurally perceived material in any cultural tradition. Composer and theorist Paul Hindemith in his Traditional harmony discussed the loss of prestige which conventional harmony teaching had suffered. More recently, its rules would "have interest only for the backward-glancing and analytical student." (page iii)[11] The range of concepts studied in music schools should not be restricted to classical and more traditional types of music. The most recent discussion on musicology has pointed out that the borders separating composition and song writing, concert music and aural tradition, are not as easy to define as previously assumed.

In the second half of the 20th century a significant number of books were published with the term 'functional harmony' in the title. The focus of these was restricted to the harmonic functions of tonic, dominant and subdominant. Conversely, ancient treatises failed to fully describe the syntax of chord progressions but exceeded in rules about voice leading.

Brazilian authors including Francischini[12] Chediak[2] Nascimento[13] Brisolla[14] Guest[4] Lemos andAguiar[15] Silva[16] Vicente[17] and others such as Lilja[18] Tagg[8] and Sessions[19], used the notion of functional harmony in their writings. Nevertheless, it is remarkable how ancient notions can also explain chord progressions in song writing in general and in Brazilian popular songs in particular. Such notions are based on concepts of functional harmony as well, although dealing with voice leading in detail. With respect to bossa nova style, it is possible to assert the primacy of harmony over melody, the same way as Jean-Philippe Rameau did in the 18th century.[20]

As demonstrated above, various chapters in Spossobin's Manual thoroughly and accurately explain chord progressions such as those used in Brazilian popular songs. This manual, and other such treatises on harmony as Koechlin[21], Zamacois[5] Rimski-Korsakov[6], and Persichetti[22] can certainly be used as a scholarly tool to analyze music of the past, as well as popular song writing.

\section{Appendix}

I. Inclination:

1. "Vira a casaca" (Support another team) by Joubert de Carvalho and Gáudio Viotti

PIXINGUINHA. No tempo dos oitobatutas. Curitiba: Revivendo, 1995

2. "João e Maria" (John and Mary) by Chico Buarque and Sivuca.

NARA LEÃO. Meus amigos são um barato. Rio de Janeiro: Philips, 1977.

3. "Água de beber" (Drinking water) by Tom Jobim and Vin ícius de Moraes

TOM JOBIM. Antonio Carlos Jobim, the composer of Desafinado plays. Los Angeles: Verve, 1963.

4. "Look to the sky" by Tom Jobim

TOM JOBIM. Wave. Los Angeles: A\&M Records, 1967.

5. "O bêbado e a equilibrista" (The alcoholic and the man on wire) by JoãoBosco and Aldir Blanc

ELIS REGINA. Essamulher. Rio de Janeiro: WEA, 1977.

6. "Na intimidademeupreto" by Nei Lopes 
CASUARINA. Casuarina. Rio de Janeiro: BiscoitoFino, 2005.

II. Major-minor system:

Major-minor system comprises the modal interchange concept:

1. "Look to the sky" by Tom Jobim

TOM JOBIM. Wave. Los Angeles: A\&M Records, 1967.

2. "O bêbado e a equilibrista" (The alcoholic and the man on wire) by JoãoBosco and Aldir Blanc

ELIS REGINA. Essamulher. Rio de Janeiro: WEA, 1977.

3. Luiza by Tom Jobim

TOM JOBIM. Passarim. New York: Verve Records/Poly gram, 1987.

4. Gatasextraordinárias (A mazing babies) by Caetano Veloso.

CASSIA ELLER. Com vocêmeumundoficariacompleto. Rio de Janeiro: Universal, 1996.

III. Augmented sixth chord:

1. Luiza by Tom Jobim

TOM JOBIM. Passarim. New York: Verve Records/Poly gram, 1987.

2. "Sótinha de ser com você" (It must be you) by Tom Jobim

ELIS REGINA. Elis \& Tom. Los Angeles: Polygram, 1974.

3. "Derradeira primavera" (Ultimate springtime) By Tom Jobim and Vinícius de Moraes

NARA LEÃ O. Opinião de Nara. Rio de Janeiro: Elenco, 1964.

IV. Neapolitan harmonies:

1. "Gema" (Gem) by Caetano Veloso

TEREZA CRISTINA. Delicada. Rio de Janeiro: EMI Music Brasil, 2007.

2. "Bronzes e cristais" (Bronzes and crystals) by AlcyrPires Verme lho

MAYSA. ConviteparaouvirMaysa $\mathrm{n}^{\circ} 2$. Rio de Janeiro: RGE, 1958.

V. Ellipsis:

1. "Joana, a Francesa" (Joana, the French) by Chico Buarque and Francis Hime

CHICO BUARQUE. A Arte De Chico Buarque. Rio de Janeiro: Universal Music, 2004.

2. "Chorinhopraele" (Chorinho for him) by HermetoPasc oal

HERMETO PASCOAL. Missa dos escravos. Rio de Janeiro: Warner, 1977.

3. "A rã" (The frog) by JoãoDonato and Caetano Veloso

JOÃO DONATO. Quem é quem. Rio de Janeiro: EMI, 1973.

4. Estrada do sol by Tom Jobim and Dolores Duran

AGOSTINHO DOS SANTOS.Agostinho dos Santos. Rio de Janeiro: Polydor 262-a, 1958.

5. "Sótinha de ser com você" (It must be you) by Tom Jobim.

ELIS REGINA. Elis \& Tom. Los Angeles: Polygram, 1974.

VI. Seventh diminished chords:
1. Avarandado by Caetano Veloso

CAETANO VELOSO. Domingo. Rio de Janeiro: Philips, 1967.

2. Discussão by Tom Jobim and Vinícius de Moraes

JOÃO GILBERTO. O amor o sorriso e a flor. Rio de Janeiro: Odeon, 1960.

3. Entrudo by Carlos Lyra

ELIS REGINA. Elis especial. Rio de Janeiro: Philips, 1979.

4. Euseiquevouteamar by Tom Jobim and Vinícius de Moraes

TOM JOBIM. Novo Millenium. Rio de Janeiro: Universal, 2005.

5. "Feionão é bonito" (It is ugly, not beautiful) by Carlos Lyra and GianfrancescoGuarnieri

CARLOS LYRA. Carlos Lyra. Rio de Janeiro:

Continental, 1974.

6. "Look to the sky" by Tom Jobim

TOM JOBIM. Wave. Los Angeles: A\&M Records, 1967. VII. Chords with nonchord tones:

1. "Aula de matemática" de Tom Jobim e Marino Pinto

TOM JOBIM \& MIUCHA. O essencial de Miucha e Tom.

Rio de Janeiro: RCA, 1979.

2. "Euseiquevouteamar" by Tom Jobim and Vinícius de Moraes

TOM JOBIM. Novo Millenium. Rio de Janeiro: Universal, 2005.

\section{REFERENCES}

[1] Igor V. Spossobin, "Manual de harmonia", 4th ed., Música, Russia, 2007. (Russian original)

[2] Igor V. Spossobin, "Manual de harmonia", 4th ed., Música, Russia, 1965

[3] AlmirChediak, "Dicionário de acordescifrados", Vitale,Brasil, 1984.

[4] Arnold Schoenberg, "Theory of harmony", Faber, UK, 1978.

[5] Ian Guest, "Harmonia", Vol. 1 and 2, Lumiar, Brasil, 2006.

[6] Joaquin Zamacois, "Tratado de armonia", vol. 1, 2 and 3, Labor, España, 1975.

[7] Nicolai Rimski-Korsakov, "Tratadopractico de armonia", Ricordi, Argentina, 1970.

[8] Paulo Silva, "Manual de Harmonia" 6th ed. Brasil, 1962.

[9] Philip Tagg, "Troubles with tonal terminology", text submitted as contribution to Festschrift for CoriúnAharomián and Graciela Paraskevaídes, UK, November-December 2011

[10] Philip Tagg, "Definitions of terms to do with tonal polyphony", handout version 3, UK, October 2005.

[11] Silvio A. Merhy, "Bossa Nova: a permanên cia do samba entre a preservação e a ruptura", Dissertation, UFRJ, Brasil, 2001.

[12] Silvio A. Merhy, "Oscilações do Centro Tonal noschoros de Garoto", Thesis, UFRJ, Brasil, 1996. 
[13] Silvio A. Merhy, "Letra, melodia, arranjo, componentesemte nsãoem 'O morronão tem vez' de Antonio Carlos Jobim e Vinícius de Moraes”, Per Musi vol. 22, Brasil, 2010.

[14] Walter Piston, “Harmony”,Norton, USA, 1978.

[15] Paul Hindemith, "Traditional harmony", vol. 1 and 2, Schott, USA, 1968.

[16] AlexandreFrancischini, "Laurindo Almeida e a Bossa Nova: precursor oudifusor do novo estílo?" IX Congreso IASPM-AL, Venezuela, 2010.

[17] HermilsonNascimento, “A partituranaanálise da música popular: construindoumainstânciaprovisória de representação do original virtual", ANPPOM XX Congresso, ISSN 1983-5981, Brasil, 2010.

[18] CyroBrisolla, "Princípios de HarmoniaFuncional", 3rd ed. Annablume, Brasil, 2008.

[19] Julio Cesar Moreira Lemos and Werner Aguiar, “A MPB instrumental contemporânea e a produçãoviolonística de
Marco Pereira: análise da obra 'Samba Urbano'”, ANPPOM XXI Congresso, ISSN 1983-5981, Brasil, 2011.

[20] Raphael Ferreira da Silva, "A interaçãonaimprovisaçãoporm eio do sistema das inversões", ANPPOM XX Congresso, ISSN 1983-5981, Brasil, 2010

[21] Rodrigo Aparecido Vicente, "A sonoridade do Trio Surdina", ANPPOM XXI Congresso, ISSN 1983-5981, Brasil, 2011.

[22] EsaLilja, "Theory and Analysis of Classic Heavy Metal Harmony", Finish Music Library Associations, Finland, 2009.

[23] Roger Sessions, "Harmonic Practice", Harcourt, USA, 1951.

[24] Jean-Philippe Rameau, "Traité de l'harmonie", France, 1722.

[25] Charles Koechlin, "Traité de l'harmonie", Max Eschig, France, 1946.

[26] Vincent Persichetti, "Harmony”, Norton, USA, 1961. 